\title{
RESEARCH ON ARCHITECTURAL FORM AND STRUCTURAL PERFORMANCE OF THE BRICK-VAULT HALL HERITAGE IN CHINA-A CASE STUDY OF YONGZUO TEMPLE
}

\author{
QING CHUN ${ }^{{ }^{*}}$, YIJIE LIN ${ }^{2}$ AND CHENGWEN ZHANG ${ }^{3}$ \\ ${ }^{1}$ School of Architecture, Southeast University (SEU), 210096 Nanjing, China \\ e-mail: cqnj1979@163.com, (*corresponding author) \\ ${ }^{2}$ School of Architecture, Southeast University (SEU), 210096 Nanjing, China \\ e-mail: yijielin1223@ foxmail.com \\ ${ }^{3}$ School of Architecture, Southeast University (SEU), 210096 Nanjing, China \\ e-mail: zhang1chengwen@163.com
}

Keywords: Brick-vault hall, Yongzuo Temple, Architectural form, Structural performance, Finite element method

\begin{abstract}
The brick-vault hall building is a special type of architectural heritage in China, which is significantly different from the western masonry arch heritages in terms of architectural form, structure, construction technology and mechanical performance. After hundred years of natural disasters and human factors, these brick-vault hall buildings mostly have a lot of damages in different degrees. In order to understand the architectural form and the structural performance of this typical type of architectural heritage, the brick-vault hall of Yongzuo Temple was taken as an example to study. Based on the survey of three-dimensional laser scanner, the accurate geometrical dimension of the brick-vault hall of Yongzuo Temple was collected, the architectural form of this building and the relationship between the brick-vault hall building and the official-type timber structure were analyzed and illustrated. The material properties were observed with the on-site non-destructive testing method. Based on the above researches, the finite element model of the brick-vault hall of Yongzuo Temple was established with ANSYS, the structural performance of the brick-vault hall structure under the vertical load and the earthquake load were studied, respectively. Thus, the weak positions of the brick-vault hall of Yongzuo Temple were found out. The results can provide the basis for the conservation of this type of architectural heritage.
\end{abstract}




\section{INTRODUCTION}

The brick-vault hall buildings built in the Ming Dynasty (AD 1368-1644) is a unique type of Chinese architectural heritages. The architectural forms of these brick-vault hall buildings are very similar with those of the traditional timber building at that time, but they were usually built with grey bricks and lime mortar. For this type of architectural heritages, the brick-arch structures were mainly adopted to bear the floor load and the roof load. This type of architectural heritages has significant historical, artistic, and scientific value. In order to scientifically conserve these architectural heritages, their architectural forms and structural performance need to be studied first.

At present, some researches on brick vaults have been put forward. Gong [1] studied the architectural form and structural technology of the brick-vault hall buildings of the Ming Dynasty. Guo [2] presented the architectural characteristics and classification of the brick-vault hall buildings by investigating and mapping some brick-vault hall buildings in Beijing area. Zhu [3] and Wang [4] discussed the decorative arts and crafts of the brick-vault hall of the Longchang Temple. Chang [5] studied the historical evolution of the brick-vault buildings in China. Jin [6] presented the architectural arts of the brick-vault hall of Yongzuo Temple. Ma [7] studied the properties of tube-shaped arches, T-shaped arches, cross arches and buttress shaped arches in residential houses on the Loess Plateau. Madalena Ponte [8] built up an architectural model of the National Palace of Sintra in Portugal by BIM software. Gunes Baris [9-10] rehabilitated the particular masonry structure of a vaulted ruin located on the historical

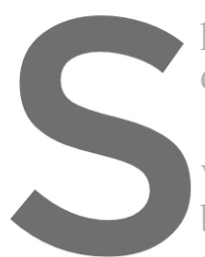

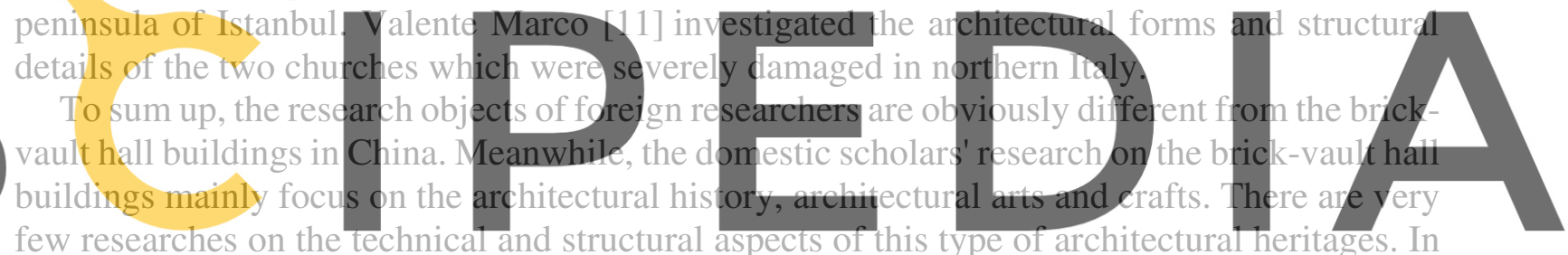
this study, the brick-vault hall building of Yongzuo Temple was taken as a typical case, and the

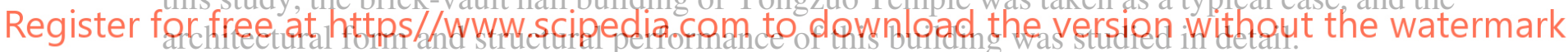

\section{ARCHITECTURAL FORM}

\subsection{The on-site investigation of this building}

The brick-vault hall of Yongzuo Temple in Taiyuan is a very typical brick-vault hall building built in the Ming Dynasty, its roof style is Chinese traditional Xieshan type, it has two floors, a width of five bays in the first floor, and a width of three bays in the second floor. The current state of the brick-vault hall of Yongzuo Temple was shown in Figure.1. The accurate geometrical information of this building was obtained through the on-site survey with 3D laser scanner. The scanning cloud points of this building were shown in Figure.2. 


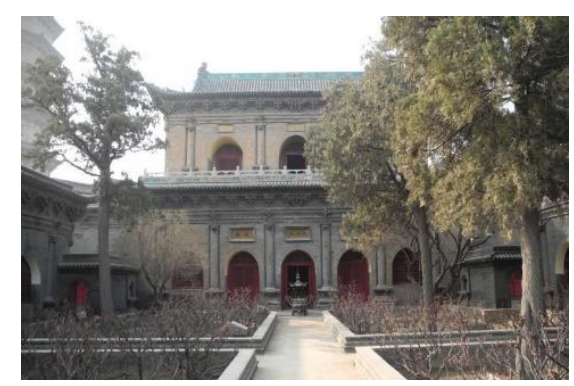

(a) The outdoor appearance

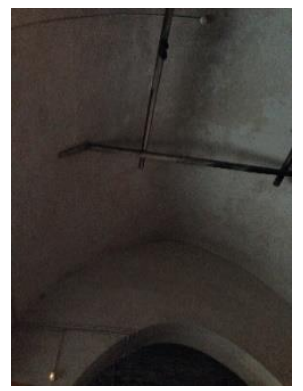

(b) The indoor appearance

Figure 1: The brick-vault hall of Yongzuo Temple

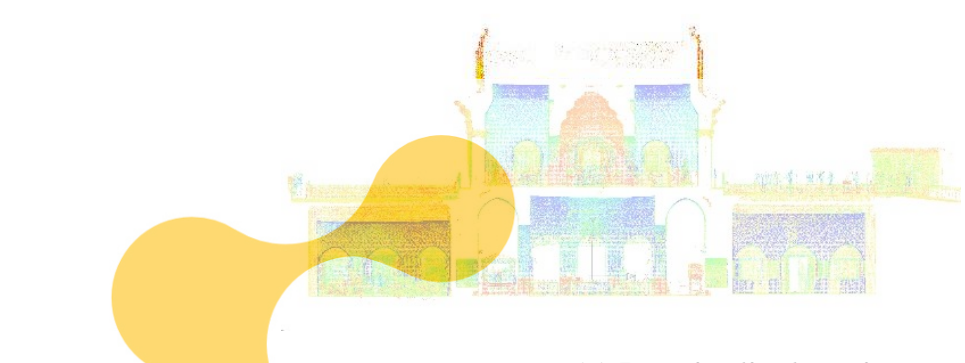

(a) Longitudinal section

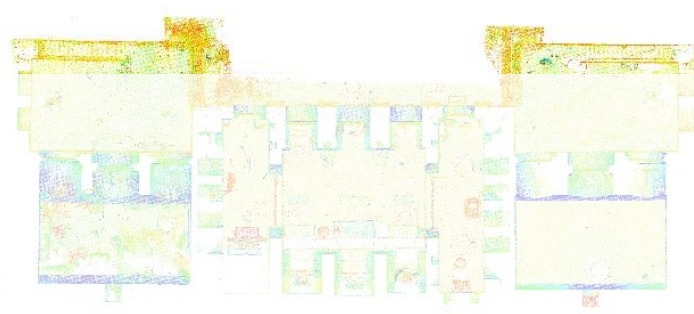

(b) The first plan
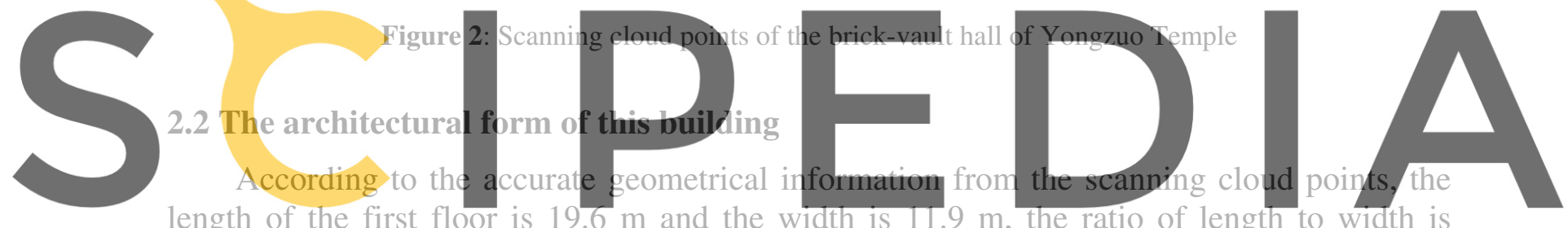

length of the first floor is $19.6 \mathrm{~m}$ and the width is $11.9 \mathrm{~m}$, the ratio of length to width is

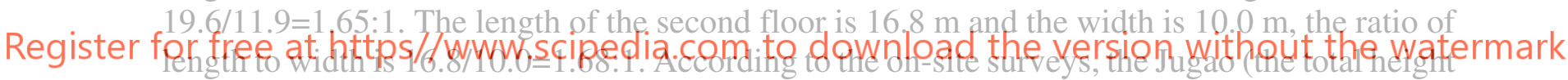

of roof) of this building is $3.820 \mathrm{~m}$, the span between the front eave purlin and the back eave

puriin is $10.870 \mathrm{~m}$, the ratio of height to span is $3.820 / 10.870=1: 2.85$. The building roof is curve, the one side of the roof can be divided into five parts as shown in Figure.3, the height, the span and the ratio of height to span of each part is shown in Table.1.

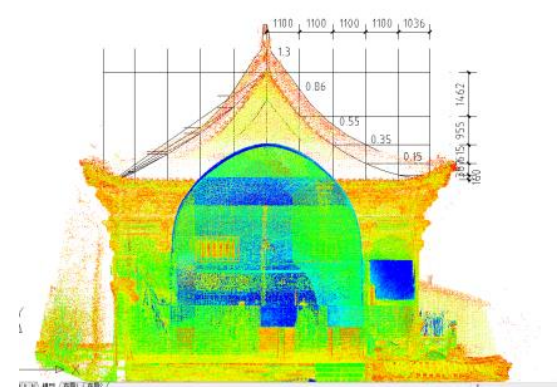

Figure 3: Roof form analysis of the brick-vault hall of Yongzuo Temple 
Table 1: Roof height and roof span of the brick-vault hall of Yongzuo Temple

\begin{tabular}{cccccc}
\hline Location & Part 1 & Part 2 & Part 3 & Part 4 & Part 5 \\
\hline Span & $1.036 \mathrm{~m}$ & $1.100 \mathrm{~m}$ & $1.100 \mathrm{~m}$ & $1.100 \mathrm{~m}$ & $1.100 \mathrm{~m}$ \\
Height & $0.160 \mathrm{~m}$ & $0.387 \mathrm{~m}$ & $0.615 \mathrm{~m}$ & $0.955 \mathrm{~m}$ & $1.462 \mathrm{~m}$ \\
Height/Span & 0.154 & 0.352 & 0.560 & 0.868 & 1.329 \\
\hline
\end{tabular}

According to the analysis of Fig. 3 and Tab.1, the roof height of this building is $3.820 \mathrm{~m}$, the roof span between the front eave purlin and the back eave purlin is $10.870 \mathrm{~m}$, the ratio of height to span is 3.820/10.870=1:2.85, which is within the range of 1/3.2 1/2.7 of the traditional official-type timber buildings of the Ming Dynasty, the result shows that the architectural form of this type of brick-vault hall building is very similar with that of the traditional timber building at that time.

\section{STRUCTURAL PERFORMANCE}

The Introduction must begin immediately below, following the format of this template. In order to find out the structural performance of the brick-vault hall of Yongzuo Temple, the software of ANSYS was used to build up the finite element model of this building (Figure.4), the structural performance of the building under the vertical load and the earthquake load were analyzed, respectively.

This building is a masonry structure, based on the test data of the brick compressive strength, the mortar compressive stren th and the code for design of masonry structures
(GB50003-2011), the parameter values of the finite model were obtained as follows: the elastid
modulus is $3.024 \mathrm{GPa}$, the density is $1990 \mathrm{~kg} / \mathrm{m} 3$, the Poisson's ratio is 0.15 , the compressive
strength is $1.35 \mathrm{MPa}$ and the tensile strength is $0.17 \mathrm{MPa}$. The live lod on the roof of the
building is $0.7 \mathrm{kN} / \mathrm{m} 2$, and the live load on the floor is $3.5 \mathrm{kV} / \mathrm{m} 2$. In the finite model, there are 426,000 SOLID45 elements.

\section{Register for free at https//www.scipedia.com to download the version without the watermark}

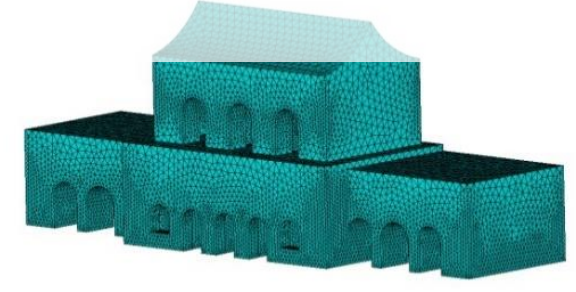

(a) The whole model

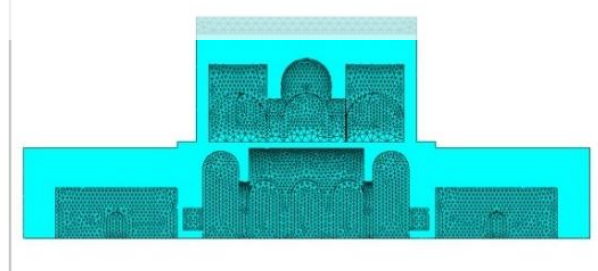

(b) The longitudinal section model

Figure 4: Finite element model of the brick-vault hall of Yongzuo Temple

\subsection{Structural performance of this building under the vertical load}

The calculation results of the first principal stresses of the brick-vault hall of Yongzuo Temple under the vertical load is shown in Figure.5. The maximum value of the first principal stress is $0.312 \mathrm{MPa}$, and the tensile strength is $0.17 \mathrm{MPa}$, the position where the first principal stress exceeds the tensile strength is easy to crack. According to the analysis results, under the 
limited vertical load, the top of the partition vault between the intermediate arch and the side arch is most prone to crack.

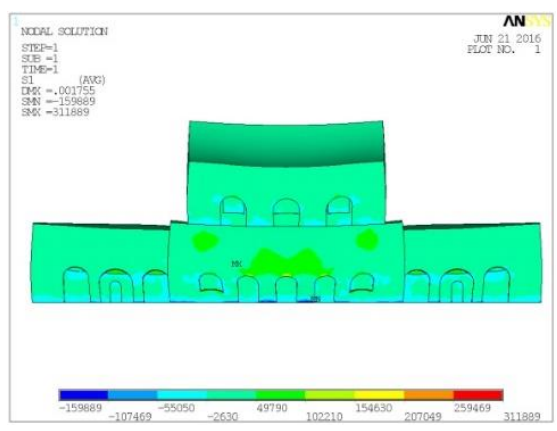

(a) North elevation

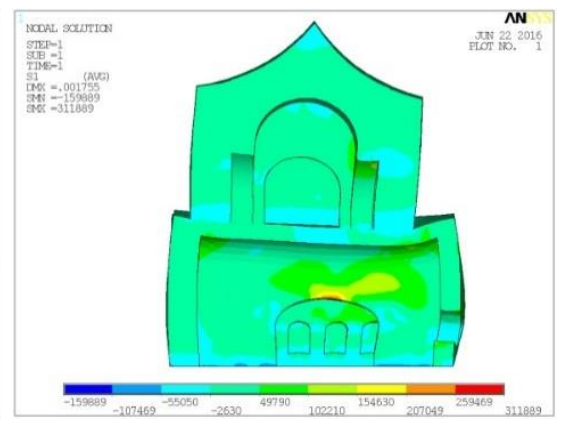

(b) Transverse section

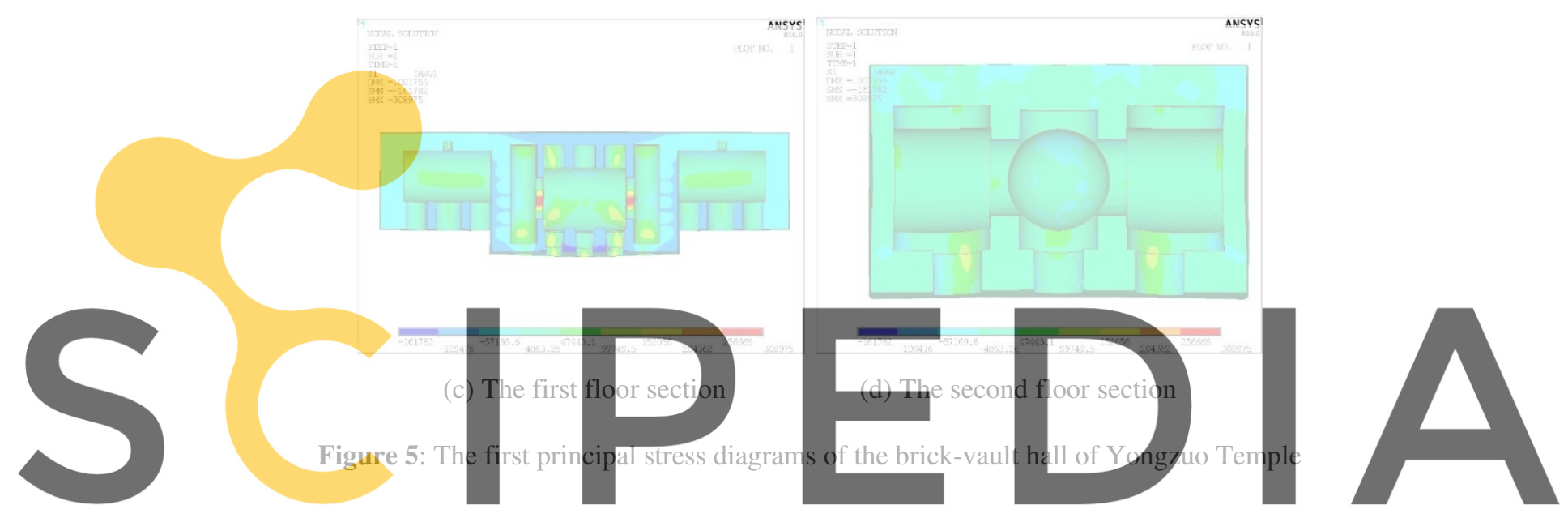

The calculation results of the third principal stresses of the brick-vault hall of Yongzuo

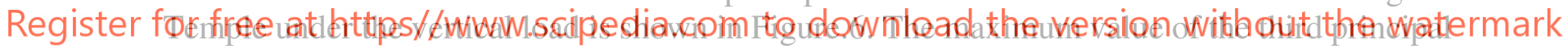
stress is $1.42 \mathrm{MPa}$, and the compressive strength is $1.35 \mathrm{MPa}$. The position where the third principal stress exceeds the compressive strength is easy to break. According to the analysis results, under the limited vertical load, the foot of the door arch at the north side is most prone to break.

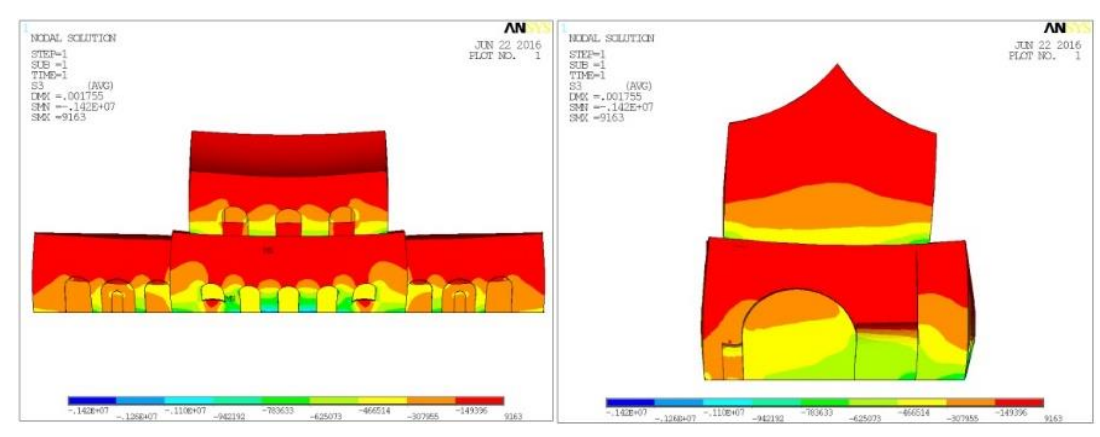

(a) North elevation

(b) East elevation 


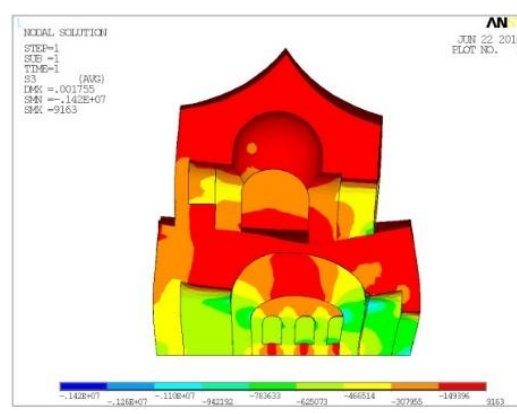

(c) Transverse section

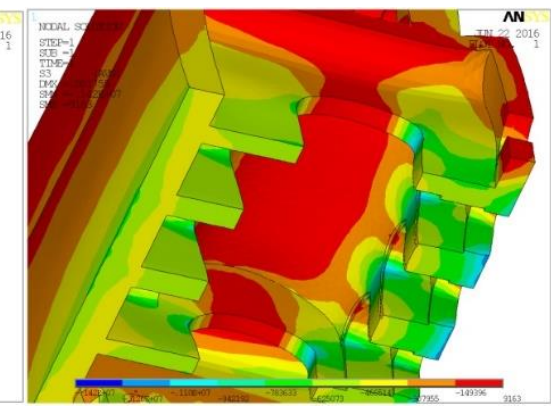

(d) The first floor arches

Figure 6: The third principal stress diagrams of the brick-vault hall of Yongzuo Temple

\subsection{Structural performance of this building under the earthquake load}

Yongzuo Temple is located in Taiyuan, Shanxi Province, where its seismic fortification intensity is 8 degree, and the design basic seismic acceleration value is $0.2 \mathrm{~g}$. The EL Centro earthquake wave was used to analyze the seismic performance of this building along the northsouth direction which has a less stiffness. The seismic wave information was shown in Fig 7. The maximum values of the seismic acceleration time history of 8-degree frequent earthquake, design earthquake, and rare earthquake are $0.70 \mathrm{~m} / \mathrm{s}^{2}, 2.00 \mathrm{~m} / \mathrm{s}^{2}$, and $3.90 \mathrm{~m} / \mathrm{s}^{2}$, respectively

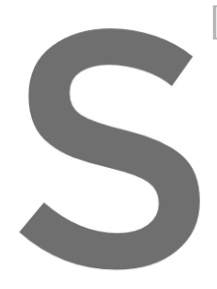
$[12]$.
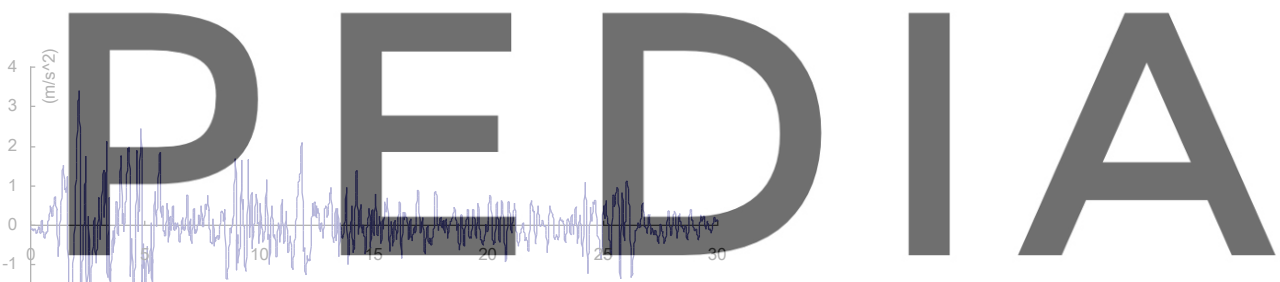

Figure 7 : EL Centro earthquake wave

In this study, a linear time-history analysis of the brick-vault hall of Yongzuo Temple under the 8-degree earthquake was carried out. Because the maximum seismic response occurred at 2.16s, so this time was selected to study the maximum first principal stress and the minimum third principal stress of the brick-vault hall of Yongzuo Temple, the stress diagrams are shown in Figure 8-9.

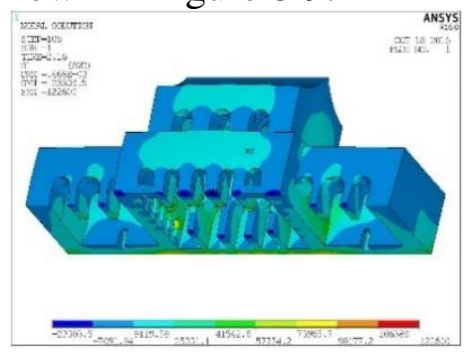

(a) frequent earthquake

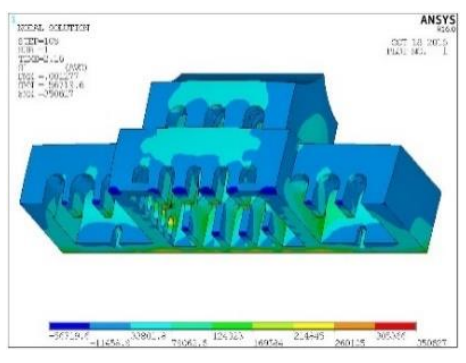

(b) design earthquake

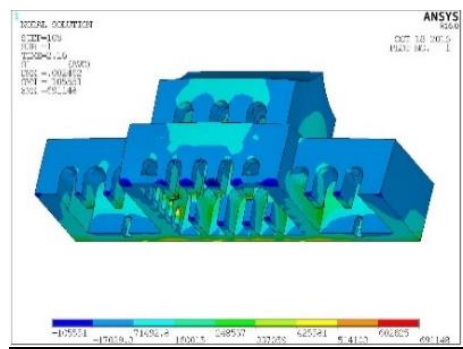

(c) rare earthquake 
Figure 8: the first principal stress diagrams

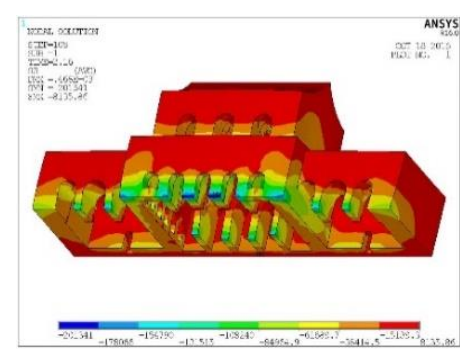

(a) frequent earthquake

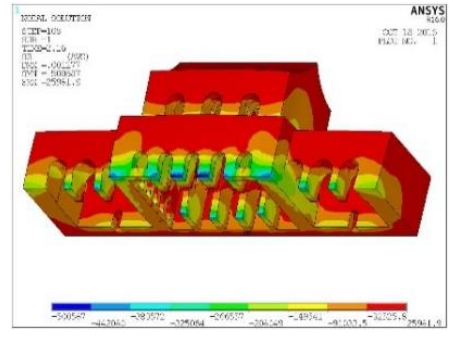

(b) design earthquake

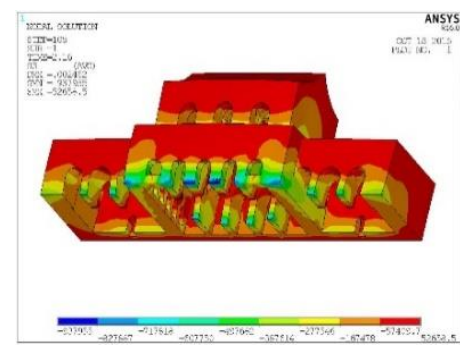

(c) rare earthquake

Figure 9: The third principal stress diagrams

The calculation results show that the third principal stresses of this building under the 8degree frequent earthquake, the 8-degree design earthquake and the 8-degree rare earthquake are all less than the compressive strength, which means there is no risk of compressive failure under the 8-degree frequent earthquake, the 8-degree design earthquake and the 8-degree rare earthquake. Under the 8-degree frequent earthquake, the first principal stress of this building is less than the tensile strength, so there will be no cracks occurred in this building. However, under the 8-degree desig in this building exceed The weak positions of $\mathrm{t}$ arch at the south side, the top of the arch of the floor are the foot of the exterior wall at the north the top of the central arch.
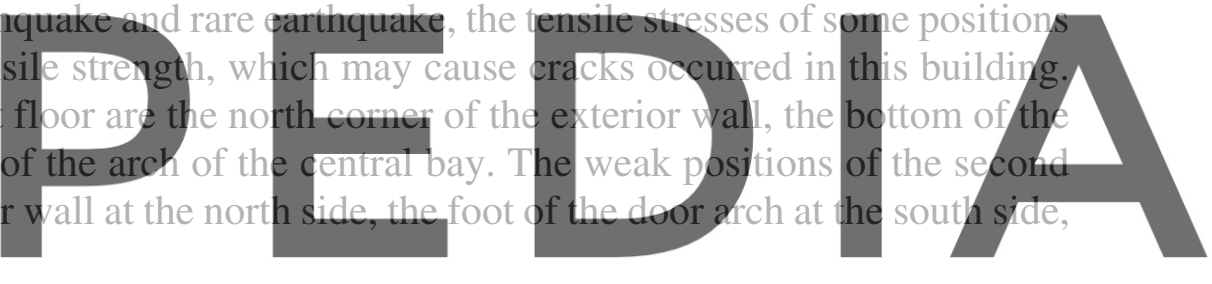

Register for freevatthtsps/MWww.scipedia.com to download the version without the watermark

The brick-vault hall of Yongzuo Temple is a very typical case of the brick-vault hall building built in the Ming Dynasty. In this study, the architectural form and structural performance of this building was studied, some conclusions can be drawn as follows:

According to the analysis of the architectural form, the roof height of this building is $3.820 \mathrm{~m}$, the roof span between the front eave purlin and the back eave purlin is 10.870 $\mathrm{m}$, the ratio of height to span is $3.820 / 10.870=1: 2.85$, which is within the range of $1 / 3.2$ $\sim 1 / 2.7$ of the traditional official-type timber buildings of the Ming Dynasty, the result shows that the architectural form of this type of brick-vault hall building is very similar with that of the traditional timber building at that time.

- $\quad$ Under the limited vertical load, the top of the partition vault between the intermediate arch and the side arch is most prone to crack, the foot of the door arch at the north side is most prone to break.

- $\quad$ There is no risk of compressive failure under the 8-degree frequent earthquake, the 8degree design earthquake and the 8-degree rare earthquake. Under the 8-degree frequent earthquake, the first principal stress of this building is less than the tensile strength, so there will be no cracks occurred in this building. However, under the 8- 
degree design earthquake and rare earthquake, the tensile stresses of some positions in this building exceed the tensile strength, which may cause cracks occurred in this building.

Acknowledgements. This study was supported by National Natural Science Foundation of China (Grant No. 51778122).

\section{REFERENCES}

[1] Gong Kai. Research on brick-vault halls of Ming Dynasty. Master Degree Thesis of Nanjing Institute of Technology. 1988.

[2] Guo Yunling. Research on the types of Wuliang halls in the Beijing area. Master Degree Thesis of Nanjing Normal University. 2014.

[3] Zhu Fuyi. The Decorative Art of Buddhist Architecture in Ming Dynasty Brick Sculptures of Longchang Monastery. Traditional Chinese Architecture and Gardens, (2015)03:45-48.

[4] Wang Xueqin, Zhao Xin. Research on the architectural decorative art of the brick-vault halls of Ming Dynasty, a case of the brick-vault hall of Longchang Temple. Movie Review, (2012) 15:91-94

[5] Chang Qing. On the evolution of ancient Chinese brick and stone vaulted buildings in the Yuan and Ming Dynasties. Studies in the History of Natural Sciences. 12(1993) 2:192-200.

[6] Jin Zhiqiang, Arcaitecture and Architects as Architecture and Gardens, (2001)01:61-64.
Ma Linyu. Study on the Arch Structure System of Chinese Folk House. Master Degree
Thesis of Xi'an Uniyersity of Architecture and Technology.2007.
Madalena Pontea, Rita Bento, Silva Daniel Vaz. A Multi-Disciphnary Approach to the
Seismic Assessment of the National Palace of Sintra. International Journal of Ar chitectural Heritage, DOI: 10.1080/15583058.2019.1648587

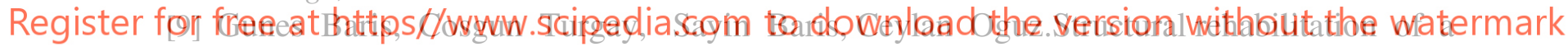
Middle Byzantine ruin and the masonry building constructed above the ruin. Part I: The ruin. Engineering Failure Analysis, 105(2019) 11:503-517.

[10] Gunes Baris, Cosgun Turgay, Sayin Baris, Ceylan Oguz.Structural rehabilitation of a middle byzantine ruin and the masonry building constructed above the ruin. Part II: The building. Engineering Failure Analysis, 105(2019) 11:527-544.

[11] Valente Marco, Milani, Gabriele. Damage survey, simplified assessment, and advanced seismic analyses of two masonry churches after the 2012 Emilia earthquake. International Journal of Architectural Heritage, (2001)13:901-924.

[12] China Academy of Building Research. Code for seismic design of buildings (2016 revision) GB50011-2010. 2016. China Architecture \& Building Press. Beijing 